\title{
Effectiveness of Costa Rica's Conservation Portfolio to Lower Deforestation, Protect Primates, and Increase Community Participation
}

\section{OPEN ACCESS}

Edited by:

Leslie Cornick,

University of Washington Bothell,

United States

Reviewed by:

Mohammad Imam Hasan Reza, Independent Researcher, Chittagong,

Bangladesh

Jonah Henri Ratsimbazafy,

Madagascar Primate Study

and Research Group, Madagascar

*Correspondence:

Michael D. Wasserman

mdwasser@indiana.edu

Specialty section:

This article was submitted to

Conservation and Restoration

Ecology,

a section of the journal

Frontiers in Environmental Science

Received: 06 July 2020

Accepted: 14 October 2020

Published: 05 November 2020

Citation:

Tafoya KA, Brondizio ES, Johnson CE, Beck P, Wallace M, Quirós $R$ and Wasserman MD (2020)

Effectiveness of Costa Rica's

Conservation Portfolio to Lower Deforestation, Protect Primates, and Increase Community Participation

Front. Environ. Sci. 8:580724. doi: 10.3389/fenvs.2020.580724

\begin{abstract}
Kathryn A. Tafoya ${ }^{1}$, Eduardo S. Brondizio ${ }^{2}$, Christopher Eric Johnson ${ }^{2,3}$, Peter Beck ${ }^{3}$, Meagen Wallace ${ }^{3}$, Rodolfo Quirós ${ }^{4}$ and Michael D. Wasserman ${ }^{*}$

${ }^{1}$ Center for the Integrative Study of Animal Behavior, Indiana University, Bloomington, IN, United States, ${ }^{2}$ Department of Anthropology, Indiana University, Bloomington, IN, United States, ${ }^{3}$ Department of Environmental Science and Policy, St. Edward's University, Austin, TX, United States, ${ }^{4}$ Organization for Tropical Studies, Las Cruces Biological Station, San Vito, Costa Rica
\end{abstract}

Common approaches to reverse the trend of tropical deforestation and loss of wildlife include systems of protected areas (PAs) such as national parks, payments for ecosystem services programs (PES) that provide financial reward to landowners protecting their forests, and ecotourism that attempts to increase local economic gains and protect biodiversity while minimizing detrimental ecological effects from tourists. For example, Costa Rica successfully reversed deforestation by restoring forest cover from $24.4 \%$ in 1985 to $>50 \%$ by 2011 through implementation of national environmental protection policies in the 1990s that included a portfolio of PAs, PES, and ecotourism. However, the social-ecological effectiveness of this conservation portfolio in terms of interactions between deforestation, biodiversity, and community participation is not clear across local scales. Therefore, we conducted multitemporal geospatial analysis to determine forest cover change from 2001-2017, broad census surveys to determine primate species richness and group encounter rate, and surveyed private landowners to determine participation in PES and ecotourism across four regions of Costa Rica. Net forest loss varied seven-fold across regions and occurred in both protected and nonprotected areas across all regions from 2001-2017, although rates were lower inside PAs. Primate group encounter rate varied significantly across all regions with an 11fold difference between the region with the most primates compared to the region with the least. All but one region contained the full community of primate species present. Participation in conservation incentives also varied seven-fold across regions, with those reporting the highest participation having the highest primate density and diversity, as well as the lowest deforestation rates. These results suggest that the most effective strategy to simultaneously curb tropical deforestation, protect primates, and ensure community benefits may depend on a complete portfolio of PAs, PES, and ecotourism, rather than a subset of these strategies. Future studies will explore finer scale differences and similarities across PA, PES, and ecotourism forests, including measures of primate physiology and behavior, forest structure, and pesticide exposure.

Keywords: tropical forests, ecotourism, protected areas, payments for ecosystem services, sustainability, biodiversity, social-ecological systems 


\section{INTRODUCTION}

As tropical rainforests contain half of all biodiversity, regulate global climate, purify air and water, and serve as a source of resources for local communities, they are crucial to the health of the planet (Gibson et al., 2011; Nolte et al., 2013). However, widespread deforestation has reduced tropical forest cover by half over the past fifty years, with a net loss of 1.5 million square kilometers globally from 2000 to 2012 (Hansen et al., 2013). The resulting loss of habitat from forest clearing and fragmentation has led to declines in wildlife populations (Laurance, 2008). Efforts to preserve the remaining forests and the threatened species dependent on them have traditionally focused on creating public protected areas (PAs), such as national parks. However, throughout the world, the inability of weak states to effectively safeguard PAs has caused many of these parks to essentially exist only on paper (Porter-Bolland et al., 2011). Especially in countries where citizens rely heavily on natural resources for subsistence and environmental laws are regularly breached, conservation policies that focus on local communities by providing economic and other incentives have become increasingly important conservation tools (Martin-Ortega and Waylen, 2018). Despite this promotion of community-based alternatives by both scholars and practitioners, little evidence exists that they are any more effective than PAs at maintaining forest quality or sustaining primate populations (Hayes, 2010; Jayachandran et al., 2017). As gaining local support is widely seen as crucial to the success of both protected area and community incentive approaches (Winkler, 2011), it is essential to improve understanding of which initiatives are more likely to not only encourage local participation, but also ensure that participation results in maintaining tropical forests and the ecosystem services they provide.

Previous studies on incentive polices have yielded mixed results. Payments for Ecosystem Services [PES or Pagos de Servicios Ambientales (PSA)] programs compensate landowners for conserving forests on their land in order to provide environmental services, including carbon fixation, hydrological services, biodiversity protection, and provisioning of scenic beauty (Chomitz et al., 1999; Morse, 2007; Morse et al., 2009). PES in Mexico has yielded small, yet positive environmental effects (Sims and Alix-Garcia, 2017; Alix-Garcia et al., 2018; Samii et al., 2014). In Brazil, PES systems in the Amazon were estimated to take 180 years to achieve significant increases in forest coverage (Ruggiero et al., 2019). In the Hoima and northern Kibaale districts of Uganda, PES programs effectively slowed deforestation rates from 9.1 to $4.2 \%$ during the 2 -year study period (Jayachandran et al., 2017). Nonetheless, other researchers have claimed that government-coordinated PES cause modest or negligible reversal of deforestation, while smaller-scale and userfinanced schemes achieve improved effectiveness (Pattanayak et al., 2010). Further research highlights funding limitations of PES, claiming that compensation often neglects the total economic value of specific ecosystem services, causing funding to account for only $0.01-8.5 \%$ of full economic value per hectare (Obeng et al., 2008). In Costa Rica, landowners enrolled in PES earned an average of $\$ 22$ to $\$ 42 /$ ha/year, while cattle farmers earned \$8 to \$125 depending on location, land type, and ranching practices (Sánchez-Azofeifa et al., 2007; Morse et al., 2009). Additionally, $15 \%$ of PES earnings were used as funds for required initial management planning and long-term monitoring (Sánchez-Azofeifa et al., 2007; Morse et al., 2009). The PES system also failed to integrate smaller landholdings, biasing enrollment qualifications toward larger properties (Zbinden and Lee, 2005). A remote sensing analysis of the first generation of PES enrollment from 1997 to 2000 found no significant reforestation in PES sites vs. non-PES sites (Sánchez-Azofeifa et al., 2001).

Studies of the effectiveness of ecotourism have also produced inconclusive findings. Scholars have questioned the negative ecological and social effects of tourist activity, including degradation of forests, anthropogenic stress on wildlife species, and increasing inequality in tourist areas (Stern et al., 2003). Others question the ability of ecotourism to generate local support and avert resource degradation (Sandbrook, 2010). For example, ecotourism has significantly affected primate behavior in Costa Rica via frequent human-wildlife interactions (McKinney, 2014), including illegal provisioned feeding systems which cause primates to develop dangerous food-raiding behaviors in national parks (Campbell, 2013). Furthermore, these harmful human-wildlife interactions expose both parties to potential zoonotic disease transmission (Muehlenbein and Wallis, 2014). Any social and ecological benefits of ecotourism can be particularly vulnerable to international geopolitical events, such as the current COVID-19 pandemic and concerns over human transmission of the virus to non-human primates (Santos et al., 2020), which has caused a shutdown on research and tourist activities. More broadly, mass ecotourism is known to have deleterious effects on whole ecosystems, including habitat destruction, forest degradation, trail erosion, pollution, and solid waste generation (Buchsbaum, 2004; Weaver, 2009). For instance, Costa Rica's Manuel Antonio National Park suffers from overcrowding, inadequate planning, overdevelopment in the adjacent communities, and improper water disposal (Weaver, 2009). Nonetheless, proponents of ecotourism argue that it can provide economic returns competitive with other land uses (Stern et al., 2003; Kirkby et al., 2010). For example, 2.6 million tourists contribute $\$ 2.85$ billion to the Costa Rican economy annually, outcompeting exports such as pineapples and bananas and accounting for almost one-third of national revenue (Sanchez, 2018). Research in the Osa Peninsula showed significant social, economic, and environmental benefits of ecotourism (Zambrano et al., 2010). These contradictory findings highlight the need for increased study of the impacts of ecotourism.

To evaluate the effectiveness of PAs, PES, and ecotourism to conserve tropical forests and wildlife living in them as a combined portfolio, we applied an integrated social-ecological approach to measure deforestation, primate diversity and abundance, and local community participation across four regions of Costa Rica. Specially, we had three main questions: (1) How much did the local community participate in conservation across regions? (2) Were deforestation rates different inside and outside of PAs, as well as across regions? and (3) Were primate species richness and group encounter rates different across regions? It was expected that regions with the greatest combined implementation of PAs, 
ecotourism, and PES with local community involvement would have the lowest rates of deforestation and highest rates of primate encounters of the entire primate community.

\section{MATERIALS AND METHODS}

\section{Study Country}

Costa Rica presents a unique case study to evaluate the socialecological effectiveness of a conservation portfolio as such an analysis has not occurred there since 2005 despite Costa Rica's seeming success at reversing deforestation that has caused the nation to be widely cited as a model of effective tropical forest conservation policies (Buchsbaum, 2004; Sánchez-Azofeifa et al., 2007; Robalino et al., 2015). Starting in the 1930s, Costa Rica's expanding population, access to logging and agriculture technology, and new land titling laws contributed to a period of expanding deforestation (de Camino et al., 2001). Since the 1950s, forests were increasingly converted into pastureland and cropland due to expanding road systems, low cost of livestock, and policies that rewarded deforestation as a means to secure land titling (Chomitz et al., 1999; Kleinn et al., 2002). Deforestation of primary and secondary rainforest increased from $46,500 \mathrm{ha} /$ year in the $1950 \mathrm{~s}$ to $50,000 \mathrm{ha} /$ year in the 1970s (de Camino et al., 2001; Kleinn et al., 2002). According to Costa Rica's Ministry of Environment and Energy (MINAE) and National Forestry Fund (FONAFIFO), national forest cover fell to its lowest point in 1985 at 24.4 - 29.5\% (Kleinn et al., 2002). Decreases in forest loss and increases in reforestation accelerated after the passing of the 1995 Environmental Law 7554 that "mandates a 'balanced and ecologically driven environment' for all," the 1996 Forestry Law 7575 that "mandates 'rational use' of all natural resources and prohibits landcover change in forests," and the 1998 Biodiversity Law that "promotes the conservation and 'rational use' of biodiversity resources" (Sánchez-Azofeifa et al., 2007). The Forestry Law specifically prohibited the conversion of natural forest to any other land use and implemented the voluntary Payments for Ecosystem Services (PES or PSA) program (Morse et al., 2009). FONAFIFO administers funding for PES using revenue from the 15\% consumer tax on fossil fuels (Sánchez-Azofeifa et al., 2007). The Biodiversity Law created the National System of Conservation Areas (SINAC) as a program within the MINAE, which manages PES enrollment and implementation (Sánchez-Azofeifa et al., 2007). The creation of SINAC also centralized management of various conservation strategies, including 11 conservation areas, thereby integrating the National Parks System (NPS) established in 1969 with biological reserves, absolute natural reserves, wildlife refuges, national wetlands, forestry reserves, and protected zones (González-Maya et al., 2015; Sanchez, 2018; Table 1). Costa Rica's PAs currently include 32 national parks and 230 other PAs, which cover 25-28\% of land area (Sinac and Minae, 2017; Sanchez, 2018). These PAs often support neighboring privately owned businesses through ecotourism (Sinac and Minae, 2017; Sanchez, 2018). Since the establishment of these environmental policies, Costa Rica restored forest cover to $50 \%$ by the 2010 s
(Garcia-Ulloa and Koh, 2016), including over 237,550 ha of land enrolled in PES contracts (Sanchez, 2018).

Moreover, the effects of these approaches on wildlife are even less understood (Sánchez-Azofeifa et al., 2007; Morse et al., 2009; Pattanayak et al., 2010; Garcia-Ulloa and Koh, 2016). This is especially crucial for primates as $60 \%$ of recognized primate taxa are currently classified as vulnerable, endangered, or critically endangered by the IUCN (McKinney, 2015). Therefore, focusing on Costa Rica's four arboreal primate species, the endangered Geoffroy's spider monkey (Ateles geoffroyi), vulnerable squirrel monkey (Saimiri oerstedii), vulnerable mantled howler monkey (Alouatta palliata), and white-faced capuchins (Cebus capucinus), allows for a critical, holistic analysis linking local community participation, deforestation, and wildlife diversity (Cuarón et al., 2008; Wong et al., 2008; McKinney, 2015). Given that tropical forests depend on primates as ecosystem engineers through seed dispersal effects on forest regeneration and tree species composition and diversity, focusing on these species is particularly relevant to continued reforestation efforts (Lambert and Garber, 1998; Pacheco and Simonetti, 2000; Kaplin and Lambert, 2002; Nuñez-Iturri and Howe, 2007; Chapman et al., 2013; Defler, 2013).

\section{Study Regions}

Data were collected across four regions of Costa Rica in 201819, with each region centered at Piro, Las Cruces, or La Selva Biological Stations or Manuel Antonio National Park (Figure 1). Within each region, PAs and privately owned forest fragments participating in PES and ecotourism to varying degrees (hereafter referred to as "sites") were sampled.

In the southwest Osa Peninsula, the Piro Biological Station $\left(8^{\circ} 24^{\prime} 42^{\prime \prime} \mathrm{N}, 83^{\circ} 20^{\prime} 00^{\prime \prime} \mathrm{W}\right)$ region contains lowland tropical rainforest, receives $\sim 3400 \mathrm{~mm}$ annual rainfall, and experiences a dry season from January to March (Goldberg et al., 2009). Protected areas comprise $80 \%$ of the Osa peninsula, with the majority in Corcovado National Park, which was established in 1975 (Sánchez-Azofeifa et al., 2007). Despite the Osa peninsula’s challenges to ecotourism (i.e., geographic remoteness and heavy rainfall during the wet season leading to inaccessible sites), it is viewed locally as the best available employment opportunity (Zambrano et al., 2010). Previous studies indicate that PES in the Osa peninsula has had limited short-term effects on forest conservation, but has accelerated reforestation on agricultural land (Sierra and Russman, 2006).

Near the Panamanian border in southern Costa Rica, the Las Cruces Biological Station ( $8^{\circ} 47^{\prime} 7^{\prime \prime} \mathrm{N}, 82^{\circ} 57^{\prime} 32^{\prime \prime} \mathrm{W}$ ) region contains premontane wet forest, receives $\sim 3500 \mathrm{~mm}$ annual rainfall, and experiences a dry season from January to March (Sekercioglu et al., 2007). The Las Cruces region consists of forest fragments which have been isolated since the mid-1950s and are currently surrounded by farmland and human settlements (Sekercioglu et al., 2007). The Las Cruces Biological Station itself is home to the Wilson Botanical Garden, which attracts hundreds of researchers and ecotourists annually (Sanchez, 2018). Previous studies indicated that PES in the region had a positive socioeconomic effect on farmers during the first three 
TABLE 1 | Costa Rica's nine protected area types, their descriptions, and purposes according to the System of National Conservation Areas [adapted from Sinac and Minae, 2017].

$\begin{array}{llc}\text { Protected Area Type Definition Purpose } & \text { P }\end{array}$

Forest reserves Geographic areas formed by forests or lands of forest aptitude.

Protected areas

National parks

Biological reserves

National wildlife refuge

Wetlands

Natural monuments

Marine reserves

Marine management areas

Geographic areas formed by forests or lands of forest aptitude.

A combination of geographic, terrestrial, marine, marine-coastal, freshwater areas of national importance with one or several ecosystems in which the species, habitats and geomorphological sites are of special scientific, cultural, educational and recreational interest or contain a natural landscape of great beauty.

Geographic areas that have terrestrial, marine, marine-coastal, freshwater ecosystems, or a combination of these and species of particular interest for conservation.

Geographic areas that have terrestrial, marine, marine-coastal, freshwater ecosystems or a combination of these.

Geographic areas containing ecosystems of national importance with dependence on aquatic natural or artificial, permanent or temporary, lentic or lotic, sweet, brackish or salty regimes, including marine extensions to the posterior limit of marine phanerogams or coral reefs.

Geographic areas that contain one or more natural elements of national or cantonal importance.

Coastal and/or oceanic marine areas that primarily guarantee the maintenance, integrity and viability of their natural ecosystems, benefiting human communities through the sustainable use of their resources, characterized by their low impact according to technical criteria.

Coastal and/or oceanic marine areas that are the subject of activities to guarantee the protection and maintenance of marine biodiversity in the long term, and that generate a sustainable flow of natural products and environmental services to communities.
To protect forest genetic resources to ensure the long term sustainable national production of forest resources.

To regulate hydrological regimes for the protection of soil and watersheds.

To protect and conserve natural beauties, biodiversity, sites of cultura significance, and for public recreation.

To conserve and protect biodiversity and allow research.

To conserve, research, increase and management of wild flora and fauna, especially those that are in danger of extinction.

To protect these ecosystems for the maintenance of their ecological functions and the provision of environmental goods and services.

To protect places or natural objects that, due to their unique or exceptional character, their scenic beauty, or their scientific value.

To conserve ecosystems and habitats for the protection of marine species.

To guarantee the sustainable use of marine-coastal and oceanic resources; conserve biodiversity at the level of ecosystems, species and genes; and maintain environmental services, cultural and traditional attributes. 


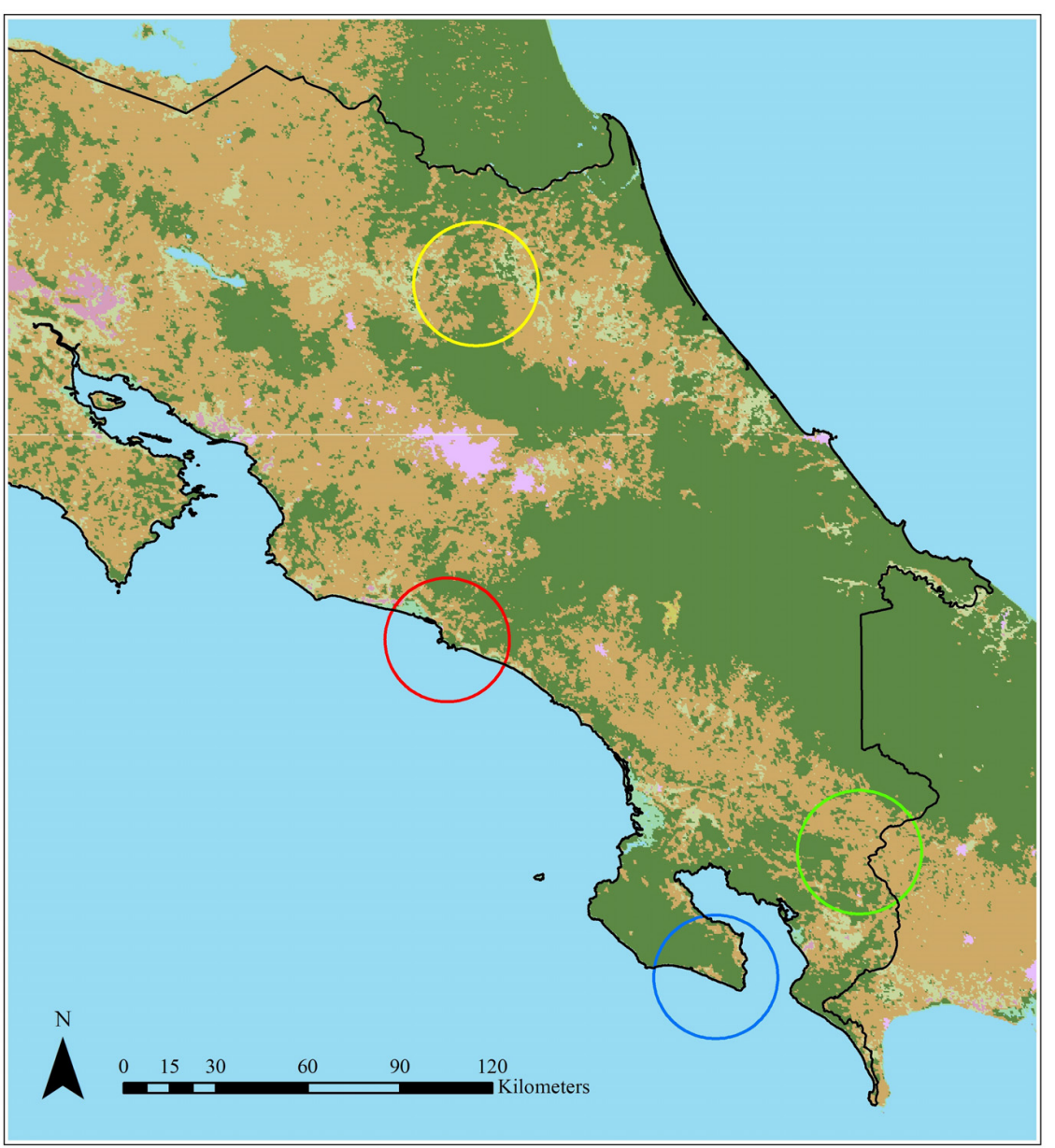

\section{Study Regions of Costa Rica}

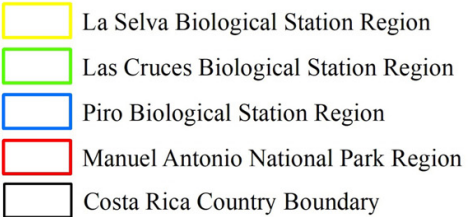

Water

Evergreen broadleaf forest

Closed shrubland

Open shrubland

Woody savanna

Savanna

Grassland

Permanent wetland

Cropland

Urban land

Cropland/natural vegetation mosaic

Non-vegetated land

FIGURE 1 | Costa Rica land cover according to MODIS UMD classification with the four study regions surrounding La Selva Biological Station, Las Cruces Biological Station, Piro Biological Station, and Manuel Antonio National Park.

years under contract, but long-term ecological effects are not well understood (Cole, 2010).

Along the central Pacific coast, the Manuel Antonio National Park (established in 1972) region contains tropical wet forest and receives $3,900 \mathrm{~mm}$ rainfall annually. The national park experiences an influx of ecotourists annually as it is the most visited and greatest income-generating park in Costa Rica (Broadbent et al., 2012). Likewise, the surrounding areas contain hotels and palm oil farms that contribute to the growing isolation of the Manuel Antonio National Park forest fragment (Broadbent et al., 2012). PES enrollment in the Manuel Antonio region is not well understood.

In the northeast, the La Selva Biological Station $\left(10^{\circ} 25^{\prime} 19.2\right.$ $\mathrm{N}, 84^{\circ} 0^{\prime} 54 \mathrm{~W}$ ) region contains lowland tropical wet forest and receives $4000 \mathrm{~mm}$ annual rainfall (McDade et al., 1994). PES efforts have been specifically targeted by the government in the San Juan - La Selva Biological Corridor due to a focus on provinces with lower socioeconomic levels and areas suitable for linking national parks (Morse, 2007). Previous studies indicated that these efforts, along with the establishment of Braullio Carrillo NP in 1978, positively influenced forest conservation and restoration (Morse, 2007). As one of the world's most researched tropical forests, La Selva draws hundreds of researchers and ecotourists annually (Sanchez, 2018).

\section{Participation in Conservation Strategies}

Regional participation in PES and ecotourism was quantitatively evaluated in each region through a total of 124 landowner surveys across the four regions in 2018 (Table 2). Surveys containing fixed-response questions were administered to local landowners orally in Spanish using local translators. Data collection followed cluster and snowball sampling methods, which utilized expert input from staff at the Organization for Tropical Studies (OTS) for identifying forest fragments for sampling (Bolt et al., 2018; Kaweesa et al., 2018). At these selected sites, every surrounding residence was approached to take the survey. Survey respondents were informed that participation was voluntary, and that they may discontinue at any time. Oral consent was obtained before data collection began. Data collection methods were preapproved by the Institutional Review Board at St. Edward's University and the University of Costa Rica's Committee on Scientific Ethics. No personal identification information was 
TABLE 2 | Landowner survey results ( $n=124)$ recording participation in conservation strategies across four regions in Costa Rica.

\begin{tabular}{lcccc}
\hline & Piro & Las Cruces & La Selva & Manuel Antonio \\
\hline PES & 0 & 0 & 2 & 0 \\
PES and ecotourism & 5 & 2 & 4 & 0 \\
Ecotourism & 9 & 6 & 12 & 3 \\
None & 2 & 52 & 24 & 3 \\
Total surveys & 16 & 60 & 42 & 6 \\
\hline
\end{tabular}

collected, and results were coded to ensure anonymity. Survey results were georeferenced and only results within each regional boundary were included.

\section{1-2017 Forest Cover Change Detection}

Land cover data were obtained from the United States Geological Survey's Land Cover Type (MCD12Q1) Version 6 data from 2001 and 2017, which were generated using data from the sensors Terra and Aqua combined Moderate Resolution Imaging Spectroradiometer (MODIS) (Friedl and Sulla-Menashe, 2019). These land cover data had a resolution of $500 \mathrm{~m}$ and were classified using the University of Maryland classification scheme (Table 3). Raster data were transformed to vector data and mapped using the South American 1969 Geographic Coordinate System (GCS) and South America Albers Equal Area Conic Projected Coordinate System (PCS). These vector data were clipped to each region for analysis. Protected area shapefile data were obtained from the Sistema Nacional de Areas de Conservación upon request (Sanchez, 2018). Nine PAs were included in this analysis (Sanchez, 2018).

To analyze deforestation rates between 2001 and 2017 in and around PAs across our four study regions, a forest change detection analysis was conducted (Naughton-Treves et al., 2005) with parameters for each region determined using ESRI's ArcMap 10.6 according to the following rules: (1) Transects for primate surveys were downloaded from a Garmin Oregon 600 as vector points. The "Points to Line" tool was used to map transects as vector lines. (2) "Mean Center" tool was used to generate the mean center point for each transect and to generate the region mean center point based on all transects in that region. This allowed us to best represent areas of study in which the most kilometers of observation took place. (3) The "Buffer" tool was used to generate a $20 \mathrm{~km}$ buffer from the region mean center point, thus encompassing all areas observed and a subsequent average buffer zone of approximately $1256 \mathrm{~km}^{2}$. The $20 \mathrm{~km}$ buffer zone allowed us to generate a regional area of interest encompassing forests where broad surveys were employed. (4) If the $20 \mathrm{~km}$ buffer zone extended beyond Costa Rica's national boundary or into water, the buffer zone was adjusted to Costa Rica's terrestrial boundary for each year using the "Clip" tool, thus providing an area of interest with potential for forest habitat growth within political boundaries enforcing environmental protection policies.

The area of each land cover type was calculated within each regional $20 \mathrm{~km}$ buffer zone for 2001 and 2017. MODIS land cover was clipped to PAs polygons and the area of each land cover type was calculated to find forest cover inside and outside PAs. Protected area polygons were erased from MODIS land cover and the area of each land cover type was recalculated to find forest cover within non-protected areas. Layers 1-5 were selected for classification as primate forest habitat. However, evergreen broadleaf forests (i.e., forests dominated by evergreen broadleaf and palmate trees with canopy $>2 \mathrm{~m}$ per $500 \mathrm{~m}$ pixels) were the only forest type detected. This classification is broadly suitable for detecting forested primate habitat, as arboreal primates are likely confined to forests fragments isolated by surroundings of greater than or equal to $\geq 500 \mathrm{~m}$ of non-forest $(<2 \mathrm{~m})$ habitat. Total deforestation rate was calculated using the Food and Agricultural Organization formula, or compound annual growth rate (in percent), as:

$$
q=\left(\left(A_{2} / A_{1}\right)^{1 /\left(t_{2}-t_{1}\right)}\right)-1
$$

where $A_{1}$ and $A_{2}$ are the forest cover at $t_{1}$ and $t_{2}$, respectively (Puyravaud, 2003). Annual forest change was also calculated as (Puyravaud, 2003):

$$
r=\left(A_{2}-A_{1}\right) /\left(t_{2}-t_{1}\right)
$$

\section{Primate Species Richness and Group Encounter Rate}

Although line-transect censuses for population density are traditionally randomly selected and cut through forests to avoid bias and effects of exposure to human activity, broad survey methods are better suited for obtaining comparative data on the presence and relative number of species for a large geographic area in a short amount of time across many sites (National Research Council, 1981; Massey, 1987; Sussman and PhillipsConroy, 1995; Sussman et al., 2003; Lehman, 2004). As surveyed sites included privately owned forest fragments and PAs where cutting trails was not allowed, broad surveys were ideal for our study and conducted according to National Research Council (1981). Existing roads, trails, streams, and creek beds were used to transverse each forest fragment. These transects were live-tracked on a Garmin GPS Oregon 600 in $1 \mathrm{~km}$ segments. Surveys were conducted along $1 \mathrm{~km}$ segments of trail that were each surveyed twice, once in the morning and once in the afternoon between 08:00-17:00 h. Transects were walked at a slow and consistent pace of $1 \mathrm{~km} / \mathrm{h}$, stopping every 50 meters for $1 \mathrm{~min}$ to listen for primate activity. When a primate group was encountered, the time, group count, age and sex composition, activity, and location data were collected in under 5 min for minimum disturbance. Individuals exhibiting the same behavior and within ten meters of another individual were considered part of the same group. A total of $230 \mathrm{~km}$ was surveyed for primates across the four regions in 2019 (Table 4). For each region, primate group encounter rate was calculated by dividing total primate groups observed per region by total kilometers walked. Primate species richness was recorded as presence or absence and reported as percent species observed of expected species in each region. To test for differences in primate group encounter rate across the four regions, an ANOVA test was run on number of primate 
TABLE 3 | MODIS land cover classification layers and descriptions [adapted from Friedl and Sulla-Menashe, 2019].

\begin{tabular}{|c|c|c|}
\hline Name & Layer & Description \\
\hline Water bodies & 0 & At least $60 \%$ of area is covered by water bodies. \\
\hline Evergreen needleleaf forests & 1 & Dominated by evergreen conifer trees (canopy $>2$ m). Tree cover $>60 \%$. \\
\hline Evergreen broadleaf forests & 2 & Dominated by evergreen broadleaf and palmate trees (canopy $>2 \mathrm{~m}$ ). Tree cover $>60 \%$. \\
\hline Deciduous needleleaf forests & 3 & Dominated by deciduous needleleaf (larch) trees (canopy > 2 m). Tree cover > 60\%. \\
\hline Deciduous broadleaf forests & 4 & Dominated by deciduous broadleaf trees (canopy $>2$ m). Tree cover $>60 \%$. \\
\hline Mixed forests & 5 & Dominated by either deciduous nor evergreen (40-60\% of each) tree type (canopy > 2 m). Tree cover $>60$ ). \\
\hline Closed shrublands & 6 & Dominated by woody perennials ( $1-2 \mathrm{~m}$ height) > $60 \%$ cover. \\
\hline Open shrublands & 7 & Dominated by woody perennials (1-2 m height) $10-60 \%$ cover. \\
\hline Woody Savannas & 8 & Tree cover 30-60\% (canopy >2 m). \\
\hline Savannas & 9 & Tree cover $10-30 \%$ (canopy > 2 m). \\
\hline Grasslands & 10 & Dominated by herbaceous annuals (<2 m). \\
\hline Permanent Wetlands & 11 & Permanently inundated lands with 30-60\% water cover and > 10\% vegetated cover. \\
\hline Croplands & 12 & At least $60 \%$ of area is cultivated cropland. \\
\hline Urban and built-up lands & 13 & At least 30\% impervious surface area including building materials, asphalt, and vehicles. \\
\hline Cropland/natural vegetation mosaics & 14 & Mosaics of small-scale cultivation 40-60\% with natural tree, shrub, or herbaceous vegetation. \\
\hline Non-Vegetated lands & 15 & $\begin{array}{l}\text { At least } 60 \% \text { of area is non-vegetated barren (sand, rock, and soil) or permanent snow and ice with less than } \\
10 \% \text { vegetation. }\end{array}$ \\
\hline Unclassified & 255 & Has not received a map label because of missing data. \\
\hline
\end{tabular}

groups observed per transect grouped by region. A Poisson linear regression was then run to determine which regions differed from one another.

\section{RESULTS}

The Manuel Antonio area of analysis was reduced from 1256.23 to $670.24 \mathrm{~km}^{2}$ after removing ocean and water-covered areas (Figure 2A). None of those surveyed in the Manuel Antonio region enrolled in PES alone or a combination of PES enrollment and participation in the ecotourism economy, while 50\% participated only in the ecotourism economy and 50\% did not participate in any of these conservation approaches (Table 5). From 2001 to 2017, the region experienced a loss of $1.02 \mathrm{~km}^{2}$ of forest per year with a deforestation rate of $0.30 \%$ for a total loss of $16.28 \mathrm{~km}^{2}$ of forest: $1.51 \mathrm{~km}^{2}$ from PAs and $14.78 \mathrm{~km}^{2}$ from nonprotected areas. Primate group encounter rate was 0.7 groups per $\mathrm{km}$ walked with seven groups observed. All four expected primate species (Cebus capucinus, Ateles geoffroyi, Alouatta palliata, and Saimiri oerstedii) were observed.

The Piro area of analysis was reduced from 1256.23 to $436.42 \mathrm{~km}^{2}$ after removing ocean and water-covered areas (Figure 2B). None of those surveyed in the Piro region were enrolled in only PES, 31\% were enrolled in PES and participated in the ecotourism economy, 56\% only in ecotourism, and $13 \%$ did not participate in any of these conservation approaches (Table 5). From 2001 to 2017, the region experienced a loss of $1.39 \mathrm{~km}^{2}$ of forest per year with a deforestation rate of $0.42 \%$ for a total loss of $22.17 \mathrm{~km}^{2}$ of forest: $4.84 \mathrm{~km}^{2}$ from PAs and $17.33 \mathrm{~km}^{2}$ from non-protected areas. Primate group encounter rate was 0.80 groups per $\mathrm{km}$ walked with 59 groups observed. All four expected primate species (Cebus capucinus, Ateles geoffroyi, Alouatta palliata, and Saimiri oerstedii) were observed.
The La Selva area of analysis was reduced from $1254.43 \mathrm{~km}^{2}$ (due to PCS distortion) to $1253.38 \mathrm{~km}^{2}$ in 2001 and $1253.17 \mathrm{~km}^{2}$ in 2017 after removing water cover (Figure 2C). Survey results indicated that $5 \%$ of those surveyed enrolled only in PES, $10 \%$ were enrolled in PES and participated in the ecotourism economy, $29 \%$ only in ecotourism, and $56 \%$ did not participate in any of these conservation approaches (Table 5). From 2001 to 2017 , the region experienced a loss of $5.19 \mathrm{~km}^{2}$ of forest per year with a deforestation rate of $1.04 \%$ for a total loss of $82.97 \mathrm{~km}^{2}$ of forest: $4.32 \mathrm{~km}^{2}$ from PAs and $78.65 \mathrm{~km}^{2}$ from non-protected areas. Primate group encounter rate was 0.35 groups per $\mathrm{km}$ walked with 36 groups total observed. All three expected primate species (Cebus capucinus, Ateles geoffroyi, and Alouatta palliata) were observed, as the region lies beyond Saimiri oerstedii's habitat range.

The Las Cruces area of analysis was reduced from $1256.23 \mathrm{~km}^{2}$ to $975.47 \mathrm{~km}^{2}$ after removing land beyond the national boundary (Figure 2D). None of those surveyed in the Las Cruces region enrolled only in PES, 3\% were enrolled in PES and participated in the ecotourism economy, $10 \%$ in only ecotourism, and $87 \%$ did not participate in any of these conservation approaches (Table 5). From 2001 to 2017, the region experienced a loss of $7.27 \mathrm{~km}^{2}$ of forest per year with a deforestation rate of $2.0 \%$ for a total loss of $116.33 \mathrm{~km}^{2}$ of forest: $0.02 \mathrm{~km}^{2}$ from PAs and $116.31 \mathrm{~km}^{2}$ from non-protected areas. Primate group encounter rate was 0.07 groups per $\mathrm{km}$ walked with three groups observed. Only one species (Cebus capucinus) of three expected primate species was observed.

Overall, deforestation rates were higher in non-protected areas than PAs across all regions, except the Manuel Antonio region, where deforestation occurred at $-0.31 \%$ in PAs and $-0.30 \%$ in non-protected areas (Table 5). The Piro region had the highest percent of forest within the area of analysis in PAs, while Las Cruces had the least percent of forest in PAs. 


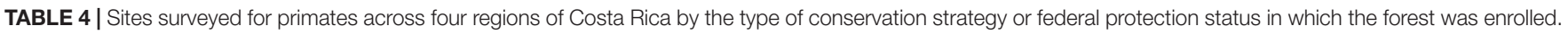

\begin{tabular}{|c|c|c|c|c|c|}
\hline & & Piro & Las Cruces & La Selva & Manuel Antonio \\
\hline \multirow[t]{5}{*}{ Protected areas } & National wildlife refuge & 4 & 0 & 3 & 0 \\
\hline & Forest reserve & 1 & 0 & 0 & 0 \\
\hline & Protected zone & 0 & 1 & 0 & 0 \\
\hline & Wetlands & 0 & 2 & 0 & 0 \\
\hline & National park & 0 & 0 & 0 & 1 \\
\hline PES & & 0 & 1 & 1 & 0 \\
\hline Ecotourism & & 3 & 0 & 1 & 1 \\
\hline PES and ecotourism & & 2 & 1 & 3 & 1 \\
\hline None & & 0 & 2 & 0 & 0 \\
\hline Total sites observed & & 5 & 7 & 5 & 2 \\
\hline Total km observed & & 74 & 42 & 104 & 10 \\
\hline
\end{tabular}

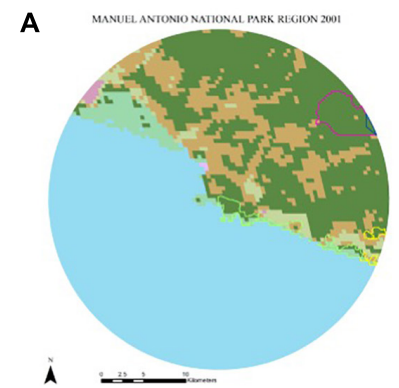

$\ddot{\Lambda}$

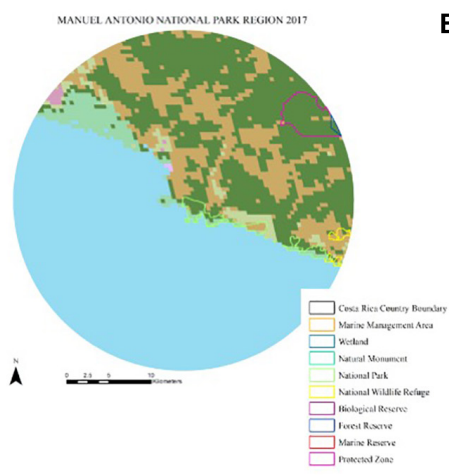

C

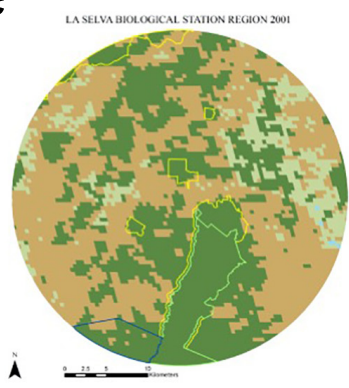

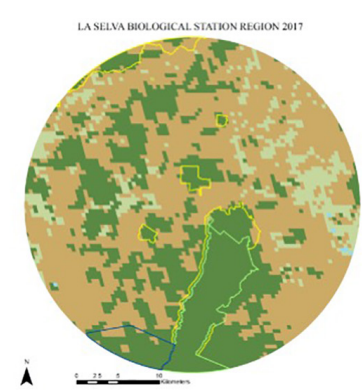

B
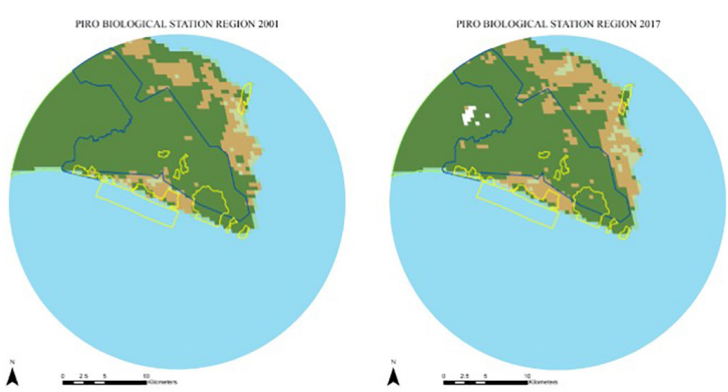

D

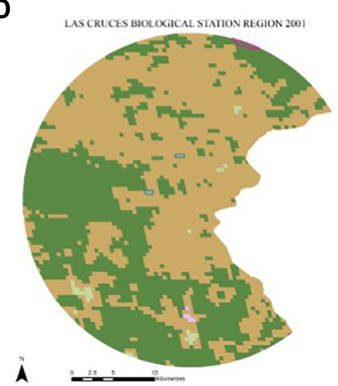

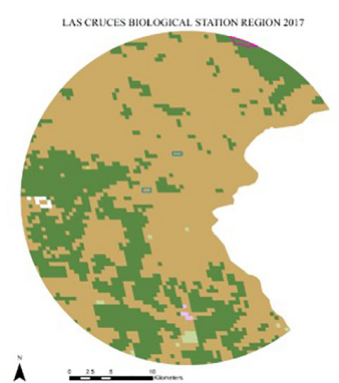

FIGURE 2 | Land cover and protected areas in 2001 and 2017 for (A) Manuel Antonio, (B) Piro, (C) La Selva, and (D) Las Cruces regions in Costa Rica used to calculate deforestation rates inside and outside of protected areas for each region.

In analyzing the difference in primate group encounter rate, the ANOVA test showed a significant difference across the four regions ( $p=0.00017)$. The Poisson linear regression showed that the Piro and La Selva regions differed from all regions except Manuel Antonio $(p<0.01)$, Manuel Antonio only differed from Las Cruces $(p<0.001)$, and Las Cruces differed from all regions $(p<0.01)$.

\section{DISCUSSION}

Net forest loss varied seven-fold across regions and occurred in both protected and non-protected areas across all regions from 2001 to 2017, although rates were lower inside PAs. Primate density varied 11-fold and number of groups observed per transect varied significantly across all regions. However, all but one region still retained the full primate community. Participation in conservation incentives also varied seven-fold across regions, with those reporting the highest participation having the highest primate density and lowest rates of deforestation. These results suggest that curbing tropical deforestation may depend on a complete portfolio of PAs, PES, and ecotourism to protect forests and primates, rather than a subset of these strategies.

The Las Cruces region stood apart from the other regions with the highest deforestation rate. Almost all of this deforestation occurred outside of its PAs. Although the Las Cruces region did have the lowest deforestation rate within PAs, it had the fewest and smallest PAs with only $1.5 \mathrm{~km}^{2}$ of protected forests in 2017 . The region also had the lowest participation in PES or ecotourism 
TABLE 5 | Primate and forest change metrics, along with community participation in conservation approaches, compared across four regions of Costa Rica.

\begin{tabular}{|c|c|c|c|c|c|c|}
\hline & & & Piro & Las Cruces & La Selva & Manuel antonio \\
\hline \multirow{3}{*}{\multicolumn{2}{|c|}{ Primate metrics }} & Primate density (groups/km) & 0.80 & 0.07 & 0.35 & 0.7 \\
\hline & & Total observed primate groups & 59 & 3 & 36 & 7 \\
\hline & & Species richness (\% of species present) & 100 & 33 & 100 & 100 \\
\hline \multirow[t]{6}{*}{ Forest change metrics } & \multirow[t]{2}{*}{ Regional } & Annual forest change (km²/year) & -1.39 & -7.27 & -5.19 & -1.02 \\
\hline & & Deforestation rate (\%) & 0.42 & 2.00 & 1.04 & 0.30 \\
\hline & \multirow[t]{2}{*}{ Protected areas } & Annual forest change $\left(\mathrm{km}^{2}\right)$ & -0.30 & -0.001 & -0.27 & -0.09 \\
\hline & & Deforestation rate (\%) & 0.11 & 0.09 & 0.18 & 0.31 \\
\hline & \multirow[t]{2}{*}{ Non-protected areas } & Annual forest change $\left(\mathrm{km}^{2}\right)$ & -1.08 & -7.27 & -4.92 & -0.92 \\
\hline & & Deforestation rate (\%) & 0.60 & 2.00 & 1.40 & 0.30 \\
\hline \multirow{4}{*}{\multicolumn{2}{|c|}{ Participation in conservation strategies (\% of those surveyed) }} & PES & 0 & 0 & 5 & 0 \\
\hline & & Ecotourism & 56 & 10 & 29 & 50 \\
\hline & & PES and ecotourism & 31 & 3 & 10 & 0 \\
\hline & & None & 13 & 87 & 56 & 50 \\
\hline
\end{tabular}

at $13 \%$. The lack of PAs, local community participation, and high deforestation rate may contribute to the lack of primates here where we documented the lowest primate group encounter rate and observed only one species. However, many factors influence primate abundance and diversity, such as historical processes like previous hunting pressure or pollution, nutritional availability, predator density, or climate, which were outside the scope of our study. Future studies should explore these alternative, but not mutually exclusive, hypotheses.

The La Selva region had the second lowest level of local community participation at $44 \%$ and second highest deforestation rate with most of this deforestation occurring in its non-protected areas (94.97\% of total deforestation). Although the La Selva region had more protected area than the Las Cruces region, the similar trends in local community participation and deforestation may similarly explain this region having the second lowest primate group encounter rate, although other factors likely apply here as well. However, the increased area in PAs may explain the presence of the complete primate community compared to Las Cruces.

The Manuel Antonio region had the second highest primate group encounter rate, lowest rate of deforestation, and second highest level of community participation. Although the region had higher rates of deforestation in protected compared to non-protected areas, the majority (90.75\%) of regional deforestation occurred in non-protected areas. The region had high participation in ecotourism, but was unique in having no enrollment in PES. Having the second highest group encounter rate, along with a complete primate community, may be due to the success of this conservation portfolio, but may also be artificially high as a result of the park's isolation in an anthropogenically dominated landscape (i.e., primates likely escaped from forest fragments as they were cut down and migrated to the park), along with provisioning of resources by tourists and tourism businesses (Broadbent et al., 2012), among other factors.

Similar to the La Selva and Las Cruces regions, the Piro region experienced the majority $(78.18 \%)$ of deforestation in nonprotected areas. However, deforestation was lower than the La Selva and Las Cruces regions and local community participation was much higher $(87 \%)$. Low rates of deforestation and the highest levels of enrollment in PES and participation in the local ecotourism economy across our study regions, combined with the highest percentage of land in PAs, may explain the complete primate community presence and highest group encounter rate observed across all regions.

Protected areas are traditionally considered cornerstones of conservation (Naughton-Treves et al., 2005), but scholars recognize that their success greatly depends on the actions of local communities living along their borders (Wittemyer et al., 2008). Although little previous evidence exists to support the idea that local community participatory models improve conservation outcomes (Hayes, 2010), our findings indicate that a complete portfolio including PAs with local community incentives may improve conservation of tropical forests and their primates. Further research incorporating experimental controls could help corroborate these findings. Previously documented failure of participatory models often results from the design of participation that does not cede control to local people, but instead operates as a means to achieve compliance with protected area rules. As a result, there is often little inclusion of local communities in actual decision-making and managerial responsibilities (de los Angeles Somarriba-Chang and Gunnarsdotter, 2012). Including meaningful local community involvement can produce more effective and equitable decisions, as well as decisions that are more likely to be followed (Ostrom, 2008). Milne and Niesten (2009) further emphasize that participation in project design is particularly important for PES programs. The low levels of participation in and knowledge of incentive programs among our respondents could indicate a lack of collaboration with local communities in the program design.

Broadening inclusion across Costa Rica could further increase success of the conservation portfolio examined here, especially in regions with current low participation. Despite the potential benefits, encouraging collaboration may be difficult as the transaction costs of participating, combined with the historical antagonism between park authority and local communities, present formidable barriers to cooperation (Mutanga et al., 2015). These transaction costs, especially the cost and time required to apply, were cited by several 
landowners explaining their lack of participation in the incentive programs. Furthermore, collaborations can be time consuming with partnerships dominated by and benefiting the more powerful partner, thus limiting localized social-ecological benefits (Youtie and Bozeman, 2016; Schröter et al., 2018; Bergsten et al., 2019). Cultural and linguistic differences, diverse interests and capabilities, and limited funding can also reduce the effectiveness of collaborations (Ulnicane, 2015; Jiren et al., 2018; Partelow and Nelson, 2018). Our survey responses indicated that the relatively small amount of PES payments influenced landowners' decision not to participate, thus mirroring previous studies (Arriagada et al., 2015). Moreover, that large landowners were more likely to participate in incentive programs further supports previous studies indicating that farm size and poverty level are important determinants of PES enrollment (Le Velly and Dutilly, 2016). Although the Costa Rican government altered the selection criteria attempting to increase participation by smaller landowners (Porras et al., 2013), our findings indicate that this is still a limitation of the program.

Collaborations that provide opportunities for knowledge exchange, reciprocal interaction, and trust are most effective (Jean et al., 2018; Abrahams et al., 2019; Bergsten et al., 2019). Thus, partners with high social capital, expansive social networks, and central positions in those networks will be crucial to facilitating conservation collaboration through their access to social-ecological information and ability to develop new relationships within and beyond local communities (Mbaru and Barnes, 2017; Jean et al., 2018; Bergsten et al., 2019). Research stations, which were central to our ability to conduct this research, meet many of these qualifications for being central partners connecting disparate conservation approaches through their connections with local communities, governmental agencies, non-governmental organizations, tourists, students, and researchers (Beck et al., 2019). Improving use of research stations to more effectively facilitate collaboration between different stakeholders will likely lead to improved community participation and conservation outcomes, thus building socialecological resilience.

\section{CONCLUSION}

Our results highlight the importance of PAs combined with local participation in ecotourism and PES as an effective conservation portfolio for lowering deforestation and protecting primate diversity. As a combined public and private strategy for conservation, this combination has the potential to balance ecological and social needs. However, although low and representing only a portion of the country, the net deforestation rates across all sites indicate that Costa Rica's decades-long reforestation trend could be threatened if these rates continue or increase. Future conservation initiatives should consider that regions with high deforestation may benefit from additional PAs, PES enrollment, and promotion of ecotourism, as sites with a higher percent of land in PAs combined with high levels of community participation in PES and ecotourism (Piro, Manuel Antonio) had the lower deforestation rates and higher primate group encounter rates than sites with lower protected area coverage and lower community participation (Las Cruces and La Selva). Although limited to only four regions, thus limiting our ability to statistically test the trends described here and hypotheses presented to explain those trends, future research will expand to additional regions to further explore interactions between local community participation, deforestation, and primate species diversity and abundance and evaluate the effectiveness of variation in a conservation portfolio that includes PAs PES, and ecotourism. Ideally, areas that are matched in terms of equivalent protected area coverage would provide for improved comparisons. Areas such as the La Suerte Biological Station and Santa Rosa National Park, where historical primate population data exist, could help advance such analysis (Fedigan and Jack, 2012; Barton, 2016; Bolt et al., 2018). Moreover, the importance of non-economic benefits of forests to landowners, as well as cultural traditions about conservation and sustainability, should be examined, in addition to the conservation portfolio explored here.

\section{DATA AVAILABILITY STATEMENT}

The raw data supporting the conclusions of this article will be made available by the authors, without undue reservation.

\section{ETHICS STATEMENT}

The studies involving human participants were reviewed and approved by St. Edward's University IRB. Written informed consent for participation was not required for this study in accordance with the national legislation and the institutional requirements. The animal study was reviewed and approved by Indiana University BIACUC.

\section{AUTHOR CONTRIBUTIONS}

KT conceived of and contributed to study design, conducted field work collecting primate census data, carried out GIS and the data analyses, created all figures and tables, conducted literature review, and participated in writing of manuscript. EB conceived of and contributed to study design, provided critical feedback on theory and methods, supervised GIS analyses, and participated in writing of the manuscript. CEJ contributed to study design, managed field work, provided critical feedback on GIS analyses, and participated in writing of the manuscript. PB conceived of and coordinated the study, managed research, contributed to study design, advised social research, and participated in writing of manuscript. MW contributed to study design, conducted field work collecting social data, and participated in writing of manuscript. RQ contributed to study design, advised research process in Costa Rica, and participated in writing of the manuscript. MDW conceived of, coordinated, and supervised the study, managed research, contributed to study design, advised primate research, participated in writing of the manuscript, and provided critical feedback on theory and methods. All 
authors gave final approval for publication and agree to be held accountable for the work performed therein.

\section{FUNDING}

This work was supported by a National Science Foundation International Research Experience for Students grant (\#1559223), along with funds from Indiana University.

\section{ACKNOWLEDGMENTS}

We would like to thank the National Science Foundation (NSF) International Research Experience for Students 2019

\section{REFERENCES}

Abrahams, B., Sitas, N., and Esler, K. (2019). Exploring the dynamics of research collaborations by mapping social networks in invasion science. J. Environ. Manage. 229, 27-37. doi: 10.1016/j.jenvman.2018.06.051

Alix-Garcia, J. M., Sims, K. R., Orozco-Olvera, V. H., Costica, L. E., Medina, J. D., and Monroy, S. R. (2018). Payments for environmental services supported social capital while increasing land management. Proc. Natl. Acad. Sci. U.S.A. 115, 7016-7021. doi: 10.1073/pnas.1720873115

Arriagada, R. A., Sills, E. O., Ferraro, P. J., and Pattanayak, S. K. (2015). Do payments pay off? evidence from participation in Costa Rica's PES Program. PLoS One 10:e131544. doi: 10.1371/journal.pone.013 1544

Barton, M. C. (2016). Vegetation Structure of a Costa Rican Forest Fragment and the Genetic Structure of the Inhabitant Alouatta Palliata Population. Available online at: https://epublications.regis.edu/theses/699 (accessed July 1, 2019).

Beck, P., Quirós, R., Johnson, C. E., and Wasserman, M. D. (2019). Biological research stations as central nodes in promoting North-South collaborative networks for teaching and research. Curr. Opin. Environ. Sustain. 39, 31-38. doi: $10.1016 /$ j.cosust.2019.06.007

Bergsten, A., Jiren, T., Leventon, J., Dorresteijn, I., Schultner, J., and Fischer, J. (2019). Identifying governance gaps among interlinked sustainability challenges. Environ. Sci. Pol. 91, 27-38. doi: 10.1016/j.envsci.2018.10.007

Bolt, L. M., Schreier, A. L., Voss, K. A., Sheehan, E. A., Barrickman, N. L., Pryor, N. P., et al. (2018). The influence of anthropogenic edge effects on primate populations and their habitat in a fragmented rainforest in Costa Rica. Primates 59, 301-311. doi: 10.1007/s10329-018-0652-0

Broadbent, E. N., Zambrano, A. M. A., Dirzo, R., Durham, W. H., Driscoll, L., Gallagher, P., et al. (2012). The effect of land use change and ecotourism on biodiversity: a case study of Manuel Antonio. Costa Rica, from 1985 to 2008. Landsc. Ecol. 27, 731-744. doi: 10.1007/s10980-012-9722-7

Buchsbaum, B. D. (2004). Ecotourism and Sustainable Development in Costa Rica. M.Sc. Thesis, Virginia Tech, Blacksburg, VA.

Campbell, J. C. (2013). White-Faced Capuchins (Cebus capucinus) of Cahuita National Park, Costa Rica: Human Foods And Human Interactions. M.Sc. Thesis. Iowa State University, Ames, IA.

Chapman, C. A., Bonnell, T. R., Gogarten, J. F., Lambert, J. E., Omeja, P. A., Twinomugisha, D., et al. (2013). Are primates ecosystem engineers? Int. J. Primatol. 34, 1-14.

Chomitz, K. M., Brenes, E., and Constantino, L. (1999). Financing environmental services: the Costa Rican experience and its implications. Sci. Total Environ. 240, 157-169. doi: 10.1016/s0048-9697(99)00310-1

Cole, R. J. (2010). Social and environmental impacts of payments for environmental services for agroforestry on small-scale farms in southern Costa Rica. Int. J. Sust. Dev. World. 17, 208-216. doi: 10.1080/1350450100372 9085

Cuarón, A. D., Morales, A., Shedden, A., Rodriguez-Luna, E., de Grammont, P. C., and Cortés-Ortiz, L. (2008). Ateles geoffroyi. IUCN Red. List Threat. Spec. 2008. (accessed July 1, 2019). team, including Colleen Friedly, Desirée Nieves-Canabal, Patrick Kelleher, Jakob Pridemore, and Faith Chonko, members of the Primate Environmental Endocrinology Laboratory (PEEL) and the Center for the Analysis of Social and Economic Landscapes (CASEL) at Indiana University (IU), Yuri Kim for her expertise and advising on GIS and remote sensing methodology, and the staff, scientists, and landowners in Costa Rica, including the Organization for Tropical Studies and Osa Conservation. We also thank the government of Costa Rica for providing permission to conduct this research, including the Ministry of Environment and Energy, National System of Conservation Areas (SINAC), and National Commission for Biodiversity Management (CONAGEBIO). Finally, we thank NSF and IU for providing the funding for this research.

de Camino, R., Segura, O., Arias, L. G., and Perez, I. (2001). Costa Rica: Forest Strategy and the Evolution of Land Use. Washington, DC: The World Bank.

de los Angeles Somarriba-Chang, M., and Gunnarsdotter, Y. (2012). Local community participation in ecotourism and conservation issues in two nature reserves in Nicaragua. J. Sustain. Tour. 20, 1025-1043. doi: 10.1080/09669582. 2012.681786

Defler, T. R. (2013). Species richness, densities and biomass of nine primate communities in eastern Colombia. Fís. Nat. 37, 253-262. doi: 10.18257/ raccefyn. 8

Fedigan, L. M., and Jack, K. M. (2012). Tracking neotropical monkeys in Santa Rosa: lessons from a regenerating Costa Rican dry forest. Long-term Field Studies of Primates. Berlin: Springer.

Friedl, M., and Sulla-Menashe, D. (2019). MCD12Q1 MODIS/Terra(Aqua Land Cover Type Yearly L3 Global 500m SIN Grid V006; Database: NASA EOSDIS Land Processes DAAC [Internet]. doi: 10.5067/MODIS/MCD12Q1. 006 (accessed July 1, 2019).

Garcia-Ulloa, J., and Koh, L. P. (2016). "Payment for ecosystem services the role of REDD(in primate conservation," in An Introduction to Primate Conservation, 1st Edn, eds S. A. Wich and A. J. Marshal (Oxford: Oxford University Press), 257-268. doi: 10.1093/acprof:oso/9780198703389.003.0016

Gibson, L., Lee, T., Koh, L., Brook, B. W., Gardner, T. A., Barlow, J., et al. (2011). Primary forests are irreplaceable for sustaining tropical biodiversity. Nature 478, 378-381. doi: 10.1038/nature10425

Goldberg, C. S., Hawley, T. J., and Waits, L. P. (2009). Local and regional patterns of amphibian chytrid prevalence on the Osa Peninsula. Costa Rica. Herpetol Rev. 40, 309.

González-Maya, J. F., Víquez-R, L. R., Belant, J. L., and Ceballos, G. (2015). Effectiveness of protected areas for representing species and populations of terrestrial mammals in Costa Rica. PLoS One 10:e0124480. doi: 10.1371/journal. pone. 0124480

Hansen, M. C., Potapov, P. V., Moore, R., Hancher, M., Turubanova, S. A., Tyukavina, A., et al. (2013). High-resolution global maps of 21st-century forest cover change. Science 342, 850-853. doi: 10.1126/science.1244693

Hayes, T. (2010). Parks, people and protected areas: an institutional assessment of the effectiveness of protected areas. World Dev. 34, 2065-2074.

Jayachandran, S., De Laat, J., Lambin, E. F., Stanton, C. Y., Audy, R., Thomas, N. E., et al. (2017). Cash for carbon: a randomized trial of payments for ecosystem services to reduce deforestation. Science 357, 267-273. doi: 10.1126/science. aan0568

Jean, S., Medema, W., Adamowski, J., Chew, C., Delaney, P., and Wals, A. (2018). Serious games as a catalyst for boundary crossing, collaboration and knowledge co-creation in a watershed governance context. J. Environ. Manage. 223, 1010-1022. doi: 10.1016/j.jenvman.2018.05.021

Jiren, T. S., Bergsten, A., Dorresteijn, I., Collier, N. F., Leventon, J., and Fischer, J. (2018). Integrating food security and biodiversity governance: a multi-level social network analysis in Ethiopia. Land Use Pol. 78, 420-429. doi: 10.1016/j. landusepol.2018.07.014

Kaplin, B. A., and Lambert, J. E. (2002). "Effectiveness of seed dispersal by Cercopithecus monkeys: Implications for seed input into degraded areas," in 
Seed Dispersal And Frugivory: Ecology, Evolution And Conservation, eds D. J. Levey, W. R. Silva, and M. Galetti (Wallingford: CABI Publishing), 351-364. doi: $10.1079 / 9780851995250.0351$

Kaweesa, S., Mkomwa, S., and Loiskandl, W. (2018). Adoption of conservation agriculture in uganda: a case study of the lango subregion. Sustainability 10:3375. doi: $10.3390 /$ su10103375

Kirkby, C. A., Giudice-Granados, R., Day, B., Turner, K., Velarde-Andrade, L. M., Dueñas-Dueñas, A., et al. (2010). The market triumph of ecotourism: an economic investigation of the private and social benefits of competing land uses in the Peruvian Amazon. PLoS One 5:e13015. doi: 10.1371/journal.pone. 0013015

Kleinn, C., Corrales, L., and Morales, D. (2002). Forest area in Costa Rica: a comparative study of tropical forest cover estimates over time. Environ. Monit. Assess 73, 17-40.

Lambert, J. E., and Garber, P. A. (1998). Evolutionary and ecological implications of primate seed dispersal. Am. J. Primatol. 1, 9-28. doi: 10.1002/(sici)10982345(1998)45:1<9::aid-ajp3>3.0.co;2-\#

Laurance, W. F. (2008). Theory meets reality: how habitat fragmentation research has transcended island biogeographic theory. Biol. Conserv. 141, 1731-1744. doi: 10.1016/j.biocon.2008.05.011

Le Velly, G., and Dutilly, C. (2016). Evaluating payments for environmental services: methodological challenges. PLoS One 11:e0149374. doi: 10.1371/ journal.pone.0149374

Lehman, S. M. (2004). Biogeography of the primates of Guyana: effects of habitat use and diet on geographic distribution. Int. J. Primatol. 25, 1225-1242. doi: 10.1023/b:ijop.0000043960.87828.19

Martin-Ortega, J., and Waylen, K. A. (2018). PES what a mess? An analysis of the position of environmental professionals in the conceptual debate on payments for ecosystem services." Ecol. Econ. 154, 218-223. doi: 10.1016/j.ecolecon.2018. 08.001

Massey, A. (1987). A population survey of Alouatta palliata, Cebus capucinus and Ateles geoffroyi at Palo Verde, Costa Rica. Rev. Biol. Trop. 35, 345-347.

Mbaru, E., and Barnes, M. (2017). Key players in conservation diffusion: using social network analysis to identify critical injection points. Biol. Conserv. 210, 222-232. doi: 10.1016/j.biocon.2017.03.031

McDade, L. A., Bawa, K. S., Hespenheide, H. A., and Hartshorn, G. S. (1994). La Selva: Ecology and Natural History of a Neotropical Rain Forest. London: University of Chicago Press.

McKinney, T. (2014). Species-specific responses to tourist interactions by whitefaced capuchins (Cebus imitator) and mantled howlers (Alouatta palliata) in a Costa Rican wildlife refuge. Int. J. Primatol. 35, 573-589. doi: 10.1007/s10764014-9769- 1

McKinney, T. (2015). A classification system for describing anthropogenic influence on nonhuman primate populations. Am. J. Primatol. 77, 715-726. doi: 10.1002/ajp.22395

Milne, S., and Niesten, E. (2009). Direct payments for biodiversity conservation in developing countries: practical insights for design and implementation. Oryx 43, 530-541. doi: 10.1017/s0030605309990330

Morse, W. (2007). Payments for Environmental Services in Costa Rica: Conservation And Production Decisions Within the San Juan-La Selva Biological Corridor. Thesis, Idaho University, Moscow, ID.

Morse, W., Schedlbauer, J., Sesnie, S., Finegan, B., Harvey, C., Hollenhorst, S., et al. (2009). Consequences of environmental service payments for forest retention and recruitment in a Costa Rican biological corridor. Ecol. Soc. 14:23.

Muehlenbein, M. P., and Wallis, J. (2014). "Considering risks of pathogen transmission associated with primate-based tourism," in Primate Tourism: A Tool for Conservation, eds A. E. Russon and J. Wallis (Cambridge: Cambridge University Press), 278-287. doi: 10.1017/cbo9781139087407.021

Mutanga, C. N., Vengesayi, S., Muboko, N., and Gandiwa, E. (2015). Towards harmonious conservation relationships: a framework for understanding protected area staff-local community relationships in developing countries. J. For. Nat. Conserv. 25, 8-16. doi: 10.1016/j.jnc.2015.02.006

National Research Council (1981). Techniques for the Study of Primate Population Ecology. Washington, DC: National Academy Press.

Naughton-Treves, L., Holland, M. B., and Brandon, K. (2005). The role of protected areas in conserving biodiversity and sustaining local livelihoods. Annu. Rev. Environ. Resour. 30, 219-252. doi: 10.1146/annurev.energy.30.050504.164507
Nolte, C., Agrawal, A., Silvius, K. M., and Soares-Filho, B. S. (2013). Governance regime and location influence avoided deforestation success of protected areas in the Brazilian Amazon. Proc. Natl. Acad. Sci. U.S.A. 110, 4956-4961. doi: 10.1073/pnas. 1214786110

Nuñez-Iturri, G., and Howe, H. F. (2007). Bushmeat and the fate of trees with seeds dispersed by large primates in a lowland rain forest in western Amazonia. Biotropica 39, 348-354. doi: 10.1111/j.1744-7429.2007.00276.x

Obeng, E. A., Aguilar, F. X., and Mccann, L. M. (2008). Payments for forest ecosystem services: a look at neglected existence values, the free-rider problem and beneficiaries' willingness to pay. Int. For. Rev. 20, 206-219. doi: 10.1505/ 146554818823767528

Ostrom, E. (2008). The challenge of common pool resources. Environment 50, $8-21$.

Pacheco, L. F., and Simonetti, J. A. (2000). Genetic structure of a mimosoid tree deprived of its seed disperser, the spider monkey. Conserv. Biol. 14, 1766-1775. doi: 10.1046/j.1523-1739.2000.99182.x

Partelow, S., and Nelson, K. (2018). Social networks, collective action and the evolution of governance for sustainable tourism on the Gili Islands, Indonesia. Mar. Pol. 112:103220.

Pattanayak, S. K., Wunder, S., and Ferraro, P. J. (2010). Show me the money: do payments supply environmental services in developing countries? Rev. Environ. Econ. Pol. 4, 254-274. doi: 10.1093/reep/req006

Porras, I., Barton, D., Chacon-Cascanteband, A., and Miranda, M. (2013). Learning from 20 years of payments for ecosystem services in Costa Rica. London: IIED.

Porter-Bolland, L., Ellis, E., Guariguata, M., Ruiz-Mallen, I., Negrete-Yankelevich, S., and Reyes-Garcia, V. (2011). Community managed forests and protected areas: an assessment of their conservation effectiveness across the tropics. Forest Ecol. Manag. 268, 6-17. doi: 10.1016/j.foreco.2011.05.034

Puyravaud, J. P. (2003). Standardizing the calculation of the annual rate of deforestation. For Ecol. Manage. 177, 593-596. doi: 10.1016/s0378-1127(02) 00335-3

Robalino, J., Sandoval, C., Barton, D. N., Chacon, A., and Pfaff, A. (2015). Evaluating interactions of forest conservation policies on avoided deforestation. PLoS One 10:e0124910. doi: 10.1371/journal.pone.0124910

Ruggiero, P. G., Metzger, J. P., Tambosi, L. R., and Nichols, E. (2019). Payment for ecosystem services programs in the Brazilian Atlantic Forest: effective but not enough. Land Use Pol. 82, 283-291. doi: 10.1016/j.landusepol.2018. 11.054

Samii, C., Lisiecki, M., Kulkarni, P., Paler, L., and Chavis, L. (2014). Effects of payment for environmental services (pes) on deforestation and poverty in low and middle income countries: a systematic review. Campbell Syst. Rev. 10, 1-95. doi: $10.4073 /$ csr.2014.11

Sanchez, R. V. (2018). Conservation strategies, protected areas, and ecotourism in Costa Rica. J. Park. Recreat. Admi. 36, 115-128. doi: 10.18666/jpra-2018-v36i3-8355

Sánchez-Azofeifa, G. A., Harriss, R. C., and Skole, D. L. (2001). Deforestation in Costa Rica: a quantitative analysis using remote sensing imagery 1 . Biotropica 33, 378-384. doi: 10.1646/0006-3606(2001)033[0378:dicraq]2.0.co;2

Sánchez-Azofeifa, G. A., Pfaff, A., Robalino, J. A., and Boomhower, J. P. (2007). Costa Rica's payment for environmental services program: intention, implementation, and impact. Conserv. Biol. 21, 1165-1173. doi: 10.1111/j.15231739.2007.00751.x

Sandbrook, C. G. (2010). Local economic impact of different forms of nature-based tourism. Conserv. Lett. 3, 21-28. doi: 10.1111/j.1755-263x.2009.00085.x

Santos, W. J., Guiraldi, L. M., and Lucheis, S. B. (2020). Should we be concerned about COVID-19 with nonhuman primates? Am. J. Primatol. 82:e23158. doi: 10.1002/ajp.23158

Schröter, B., Hauck, J., Hackenberg, I., and Matzdorf, B. (2018). Bringing transparency into the process: social network analysis as a tool to support the participatory design and implementation process of payments for ecosystem services. Ecosyst. Serv. 34, 206-217. doi: 10.1016/j.ecoser.2018.03.007

Sekercioglu, C. H., Loarie, S. R., Oveido Brenes, F., Ehrlich, P. R., and Daily, G. C. (2007). Persistence of forest birds in the Costa Rican agricultural countryside. Conserv. Biol. 21, 482-494. doi: 10.1111/j.1523-1739.2007.00655.x

Sierra, R., and Russman, E. (2006). On the efficiency of environmental service payments: a forest conservation assessment in the Osa Peninsula. Costa Rica. Ecol Econ. 59, 131-141. doi: 10.1016/j.ecolecon.2005.10.010 
Sims, K. R., and Alix-Garcia, J. M. (2017). Parks versus PES: evaluating direct and incentive-based land conservation in Mexico. J. Environ. Econ. Manage. 86, 8-28. doi: 10.1016/j.jeem.2016.11.010

Sinac and Minae (2017). Áreas Protegidas de Costa Rica. Asheville: National Center for Geoenvironmental Information.

Stern, C. J., Lassoie, J. P., Lee, D. R., and Deshler, J. D. (2003). How eco is eco-tourism? J. Sustain. Tour. 11, 322-347.

Sussman, R. W., Green, G. M., Porton, I., Andrianasolondraibe, O. L., and Ratsirarson, J. (2003). A survey of the habitat of Lemur catta in southwestern and southern Madagascar. Primate Conserv. 19: 1631.

Sussman, R. W., and Phillips-Conroy, J. E. (1995). A survey of the distribution and density of the primates of Guyana. Int. J. Primatol. 16, 761-791. doi: $10.1007 / \mathrm{bf02735719}$

Ulnicane, I. (2015). Why do international research collaborations last? Virtuous circle of feedback loops, continuity and renewal. Sci. Public Pol. 42, 433-447. doi: $10.1093 /$ scipol/scu060

Weaver, D. B. (2009). Magnitude of ecotourism in Costa Rica and Kenya. Ann. Tour. Res. 26, 792-816. doi: 10.1016/s0160-7383(99)00 044-4

Winkler, R. (2011). Why do ICDPs fail? The relationship between agriculture, hunting and ecotourism in wildlife conservation. Resour. Energy Econ. 33, 55-78. doi: 10.1016/j.reseneeco.2010.01.003

Wittemyer, G., Elsen, P., Bean, W. T., Burton, A. C. O., and Brashares, J. (2008). Accelerated human population growth at protected area edge. Science 321, 123-126. doi: 10.1126/science. 1158900
Wong, G., Cuarón, A. D., Rodriguez-Luna, E., and de Grammont, P. C. (2008). Saimiri oerstedii. The IUCN Red List of Threatened Species 2008: e.T19836A9022609. (accessed July 1, 2019).

Youtie, J., and Bozeman, B. (2016). Dueling co-authors: how collaborators create and sometimes solve contributorship conflicts. Minerva 54, 375-397. doi: $10.1007 /$ s11024-016-9303-Z

Zambrano, A. M. A., Broadbent, E. N., and Durham, W. H. (2010). Social and environmental effects of ecotourism in the Osa Peninsula of Costa Rica: the Lapa Rios case. J. Ecotour. 9, 62-83. doi: 10.1080/14724040902953076

Zbinden, S., and Lee, D. R. (2005). Paying for environmental services: an analysis of participation in Costa Rica's PSA program. World Dev. 33, 255-272. doi: 10.1016/j.worlddev.2004.07.012

Conflict of Interest: RQ is the Head of Research and Education at the Organization for Tropical Studies Las Cruces Biological Station. Although he works for one of the institutions that manages two of our study sites discussed in this manuscript, the authors declare that the research was conducted in the absence of any commercial or financial relationships that could be construed as a potential conflict of interest.

Copyright (C) 2020 Tafoya, Brondizio, Johnson, Beck, Wallace, Quirós and Wasserman. This is an open-access article distributed under the terms of the Creative Commons Attribution License (CC BY). The use, distribution or reproduction in other forums is permitted, provided the original author(s) and the copyright owner(s) are credited and that the original publication in this journal is cited, in accordance with accepted academic practice. No use, distribution or reproduction is permitted which does not comply with these terms. 